\title{
Immunoglobulin derived depositions in the nervous system: novel mass spectrometry application for protein characterization in formalin-fixed tissues
}

\author{
Fausto J Rodriguez ${ }^{1}$, Jeffrey D Gamez ${ }^{1}$, Julie A Vrana ${ }^{1}$, Jason D Theis ${ }^{1}$, Caterina Giannini ${ }^{1}$, Bernd W Scheithauer ${ }^{1}$, \\ Joseph E Parisi ${ }^{1}$, Claudia F Lucchinetti ${ }^{2}$, William W Pendlebury ${ }^{3}, \mathrm{H}$ Robert Bergen II $^{4}$ and Ahmet Dogan ${ }^{1}$
}

Proteinaceous deposits are occasionally encountered in surgically obtained biopsies of the nervous system. Some of these are amyloidomas, although the precise nature of other cases remains uncertain. We studied 13 cases of proteinaceous aggregates in clinical specimens of the nervous system. Proteins contained within laser microdissected areas of interest were identified from tryptic peptide sequences by liquid chromatography-electrospray tandem mass spectrometry (LC-MS/MS). Immunohistochemical studies for immunoglobulin heavy and light chains and amyloidogenic proteins were performed in all cases. Histologically, the cases were classified into three groups: 'proteinaceous deposit not otherwise specified' (PDNOS) $(n=6)$, amyloidoma $(n=5)$, or 'intracellular crystals' $(n=2)$. LC-MS/MS demonstrated the presence of $\lambda$, but not $\kappa$, light chain as well as serum amyloid $\mathrm{P}$ in all amyloidomas. $\lambda$-Light-chain immunostaining was noted in amyloid $(n=5)$, although demonstrable monotypic lymphoplasmacytic cells were seen in only one case. Conversely, in PDNOS $\kappa$, but not $\lambda$, was evident in five cases, both light chains being present in a single case. In three cases of PDNOS, a low-grade B-cell lymphoma consistent with marginal zone lymphoma was present in the brain specimen $(n=2)$ or spleen $(n=1)$. Lastly, in the 'intracellular crystals' group, the crystals were present within CD68+ macrophages in one case wherein $\kappa$-light chain was found by LC-MS/MS only; the pathology was consistent with crystalstoring histiocytosis. In the second case, the crystals contained immunoglobulin G within CD138 + plasma cells. Our results show that proteinaceous deposits in the nervous system contain immunoglobulin components and LC-MS/MS accurately identifies the content of these deposits in clinical biopsy specimens. LC-MS/MS represents a novel application for characterization of these deposits and is of diagnostic utility in addition to standard immunohistochemical analyses. Laboratory Investigation (2008) 88, 1024-1037; doi:10.1038/labinvest.2008.72; published online 18 August 2008

KEYWORDS: mass spectrometry; amyloid; immunoglobulin; crystal-storing histiocytosis; lymphoma; nervous system

Localized, paucicellular proteinaceous deposits are occasionally encountered in biopsies of the nervous system. In some instances, the nature of these deposits may be elucidated. Their prototype is found in the amyloidoma, a localized accumulation of AL $\lambda$-light-chain-derived amyloid with a predilection for involvement of white matter, choroid plexus, and peripheral nerve. ${ }^{1-4}$ Amyloidomas are indolent lesions, and the diagnosis can be confirmed with both histochemical stains for amyloid (Congo red (CR) and sulfated Alcian blue) and immunohistochemistry for $\kappa$ - and $\lambda$-immunoglobulin light chains. Amyloid may also be seen in dural deposits of extranodal marginal zone lymphomas. ${ }^{5}$

Other light-chain-derived, non-amyloid deposits are known to occur, predominantly in extraneural sites, and usually in association with monoclonal lymphoplasmacytic disorders. The latter include light-chain deposition disease and crystal-storing histiocytosis. ${ }^{6-9}$ However, nervous system involvement by these two processes is not well characterized.

Laser microdissection of formalin-fixed paraffin-embedded tissue (FFPE), in combination with liquid chromatography

${ }^{1}$ Department of Laboratory Medicine and Pathology, Research Center, Mayo Clinic, Rochester, MN, USA; ${ }^{2}$ Department of Neurology, Research Center, Mayo Clinic, Rochester, MN, USA; ${ }^{3}$ Department of Pathology, University of Vermont College of Medicine, Burlington, VT, USA and ${ }^{4}$ Department of Proteomics, Research Center, Mayo Clinic, Rochester, MN, USA

Correspondence: Dr FJ Rodriguez, MD, Department of Laboratory Medicine and Pathology, Mayo Clinic College of Medicine, 200 First Street SW, Mayo Clinic, Rochester, MN 55905, USA.

E-mail: rodriguez.fausto@mayo.edu

Received 30 January 2008; revised 04 May 2008; accepted 05 May 2008 
and tandem mass spectrometry (LC-MS/MS), represents a technique with potential as a novel diagnostic method in surgical pathology. We hypothesized that proteinaceous deposits encountered in biopsies of the nervous system, whether demonstrating amyloid properties or not, have immunoglobulin components. In the current study, we explore the utility of laser microdissection in combination with LC-MS/MS for the evaluation of proteinaceous deposits in FFPE in this setting, and provide a rationale for their implementation as useful adjuncts to immunohistochemistry in diagnostic pathology laboratories.

\section{MATERIALS AND METHODS Patients}

The Mayo Clinic pathology records were searched for cases of amyloid, other proteinaceous material deposition (nonamyloid extracellular deposits and intracellular crystals) in brain, spinal cord, or peripheral nerve. A total of 13 (of 15) cases were included in this study. Two cases were excluded because only unstained charged slides were available for analysis. Twelve of the thirteen cases were biopsies, and 1 case was obtained from autopsy (case 9). All slides were reviewed by at least two neuropathologists (CG, JEP, FJR, BWS) and one hematopathologist $(\mathrm{AD})$. Clinical data, demographics, and follow-up information were obtained from retrospective chart review and consultation correspondence. This study was approved by the Institutional Review Board at the Mayo Clinic.

\section{Specimen Preparation and Microdissection}

The duration of storage for the FFPE tissues used in this study was variable, with a range of 6 months to 10 years. Thick $(10 \mu \mathrm{m})$ sections were placed on DIRECTOR ${ }^{\mathrm{TM}}$ slides (Expression Pathology, Gaithersburg, MD, USA) for ease of laser microdissection. The tissue was dissected directly from a charged slide in cases where paraffin blocks were not available. At least three different areas were separately microdissected and analyzed in all cases. Sections were air dried and then melted, deparaffinized, and stained in hematoxylin followed by CR. Fluorescence microscope optics was used to identify areas of CR positivity. In the non-amyloid cases the areas of interest were microdissected under bright-field microscopy into $0.5 \mathrm{ml}$ microcentrifuge tube caps containing $10 \mathrm{mM}$ Tris/1 mM EDTA/0.002\% Zwittergent 3-16 (Calbiochem, San Diego, CA, USA) using a Leica DM6000B Microdissection System (Wetzler, Germany). Collected tissues were heated at $98^{\circ} \mathrm{C}$ for $90 \mathrm{~min}$ with occasional vortexing. Following $60 \mathrm{~min}$ of sonication in a waterbath, samples were digested overnight at $37^{\circ} \mathrm{C}$ with $1.5 \mu \mathrm{l}$ of $1 \mu \mathrm{g} / \mathrm{ml}$ trypsin (Promega, Madison, WI, USA).

\section{Protein Identification Via Mass Spectrometry}

The trypsin generated digests were reduced with dithiothreitol and separated by nanoflow liquid chromatography-electrospray tandem mass spectrometry using a
ThermoFinnigan LTQ Orbitrap Hybrid Mass Spectrometer (Thermo Electron, Bremen, Germany) coupled to an Eksigent nanoLC-2D HPLC system (Eksigent, Dublin, CA, USA). A $0.25 \mu \mathrm{l}$ trap (Optimize Technologies) packed with Michrom Magic C-8 was plumbed into a 10-port valve. A $75 \mu \mathrm{m} \times \sim 15 \mathrm{~cm} \mathrm{C}-18$ column was utilized for the separation utilizing an organic gradient from 6 to $86 \%$ in $55 \mathrm{~min}$ at $400 \mathrm{nl} / \mathrm{min}$.

The Thermo-Fisher MS/MS raw data files were submitted to an in-house developed workflow tool. ${ }^{10}$ Three search algorithms (Sequest, Mascot and X!Tandem) were searched and the results assigned peptide and protein probability scores. The results were then displayed in Scaffold (Proteome Software, Portland, OR, USA). All searches were conducted with variable modifications and restricted to full trypsingenerated peptides allowing for two missed cleavages. Peptide mass search tolerances were set to 10 p.p.m. and fragment mass tolerance to $\pm 1.00 \mathrm{Da}$. The human SwissProt database was utilized (24 July 2007). Protein identifications were confirmed at the $90 \%$ confidence level and required two peptides for identification.

\section{Immunohistochemistry}

Immunohistochemical stains were performed with the aid of a DAKO Autostainer (Dako North America Inc., Carpinteria, CA, USA) using the Dual Link Envision + or ADVANCE (Dako) detection systems. Antibodies were directed against the following antigens, with the corresponding clones for the monoclonal antibodies specified: CD3 (Novocastra, Newcastke, UK; clone PS1; dilution 1:50), CD20 (Dako; clone L26; dilution 1:60), CD68 (Dako, clone KP-1; dilution 1:3000), CD138 (Dako; clone M115; dilution 1:50), Kappa Free Light Chains (Dako, polyclonal, dilution 1:6000), Kappa Light Chain (Auto ProEnzyme pretreatment; Dako; polyclonal; dilution 1:2500), Lambda Free Light Chains (Dako; polyclonal; dilution 1:2000), Lambda Light Chain (Auto ProEnzyme pretreatment; Dako; polyclonal; dilution 1:3000), Prealbumin (Transthyretin) (Dako; polyclonal; dilution 1:5000), Serum Amyloid A (SAA; Dako; clone MC-1; dilution 1:1000), and Serum Amyloid P (SAP; Biocare; polyclonal, dilution 1:20).

\section{In Situ Hybridization}

In situ hybridization with probes targeting $\lambda$ - and $\kappa$-light chain mRNA was performed on case 7 using Ventana Benchmark XT platform (Ventana, Tucson, AZ, USA) and commercially available probes (Inform $\mathbb{R}$ cytoplasmic kappa and lambda probes, Ventana) according to the manufacturer's instructions.

\section{RESULTS}

\section{Clinical Findings}

The clinical findings are summarized in Table 1 . The depositions involved brain $(n=12)$ or peripheral nerve $(n=1)$. The patients included nine women and four men. They were all adults with a median age at diagnosis of 51 
Table 1 Protein deposits in clinical specimens of the nervous system: clinical features

\begin{tabular}{|c|c|c|c|c|c|c|c|c|}
\hline Patient & Age/sex & Clinical history & Imaging & Location & Surgery & Treatment & Systemic work-up & Follow-up \\
\hline 1 & $62 / \mathrm{F}$ & $\begin{array}{l}\text { Headache, dizziness, } \\
\text { and gait problems for } \\
\text { several months; brain } \\
\text { lesions may have been } \\
\text { present for } 20 \text { years }\end{array}$ & $\begin{array}{l}\text { R parietal lobe: ring-enhancing } \\
\text { mass }(3.6 \mathrm{~cm}) \text {, moderate } \\
\text { surrounding white matter } \\
\text { edema, mass effect. } \\
\text { L temporal lobe: confluent } \\
\text { enhancing masses }(4.2 \mathrm{~cm}) \text {, } \\
\text { surrounding edema; increased } \\
\text { T1 signal, decreased T2 } \\
\text { signal in the center; stable over } \\
\text { several months }\end{array}$ & Bilateral, multifocal & $\begin{array}{l}\text { L temporal } \\
\text { craniotomy } \\
\text { with biopsy }\end{array}$ & Radiation & $\begin{array}{l}\text { Bone marrow } \\
\text { biopsy negative } \\
\text { Blood and urine } \\
\text { elecrophoresis ne- } \\
\text { gative }\end{array}$ & $\begin{array}{l}\text { Recovered well after treat- } \\
\text { ment. Lost to follow-up }\end{array}$ \\
\hline 2 & $45 / \mathrm{M}$ & $\begin{array}{l}\text { Sudden onset of } \\
\text { hemiparesis; received } \\
\text { steroids followed by } \\
\text { biopsy }\end{array}$ & $\begin{array}{l}\text { MRI: enhancing } 1.1 \mathrm{~cm} \text { lesion; } \\
\text { gradual enlargement with ring } \\
\text { enhancement development }\end{array}$ & $\begin{array}{l}\text { L posterolateral } \\
\text { thalamus/internal } \\
\text { capsule }\end{array}$ & $\begin{array}{l}\text { Stereotactic } \\
\text { biopsy }\end{array}$ & $\begin{array}{l}\text { Observation with } \\
\text { yearly MRIs. }\end{array}$ & $\begin{array}{l}\text { Chest CT-negative } \\
\text { for lesions. } \\
\text { Systemic work-up } \\
\text { not done }\end{array}$ & $\begin{array}{l}\text { Developed pulmonary } \\
\text { embolism } 2 \text { months after } \\
\text { surgery. Stable lesion on } \\
\text { yearly MRls } 2 \text { years after } \\
\text { surgery }\end{array}$ \\
\hline 3 & $40 / \mathrm{F}$ & Seizures & $\begin{array}{l}\text { Well-demarcated contrast } \\
\text { enhancing, hemispheric lesion }\end{array}$ & Brain NOS & Biopsy & NA & NA & Lost to follow-up \\
\hline 4 & $51 / \mathrm{M}$ & $\begin{array}{l}\text { Left homonymous } \\
\text { inferior quadrantonopsia }\end{array}$ & MRI: ring enhancing mass & R occipital lobe & $\begin{array}{l}\text { Stereotactic } \\
\text { biopsy }\end{array}$ & $\begin{array}{l}\text { Observation } \\
\text { followed by } \\
\text { resection }\end{array}$ & $\begin{array}{l}\text { Observation with } \\
\text { MRIs. Followed by } \\
\text { Neurosurgery only }\end{array}$ & $\begin{array}{l}\text { Persistent symptoms slight } \\
\text { enlargement on follow-up } \\
\text { MRI. Underwent resection } 1 \\
\text { month after which revealed } \\
\text { amorphous debris with a } \\
\text { mild benign polyclonal lym- } \\
\text { phoplasmacytic infiltrate. } \\
\text { No evidence of recurrence } \\
\text { after (most recent MRI } 3 \\
\text { years after diagnosis) }\end{array}$ \\
\hline 5 & $54 / \mathrm{F}$ & $\begin{array}{l}\text { Problems with balance } 5 \\
\text { years; Gait disturbance } \\
\text { most apparent } 19 \\
\text { months prior }\end{array}$ & $\begin{array}{l}\text { Periventricular, nodular, } \\
\text { perivascular, enhancing white } \\
\text { matter lesions in frontoparietal } \\
\text { lobes, } R>L \text {, progressive in } 8 \\
\text { months }\end{array}$ & Bilateral multifocal & $\begin{array}{l}\text { Stereotactic right } \\
\text { frontal biopsy }\end{array}$ & Radiation therapy & $\begin{array}{l}\text { Negative fat } \\
\text { aspirate } \\
\text { CSF normal } \\
\text { Normal serum and } \\
\text { urine electrophoresis }\end{array}$ & $\begin{array}{l}\text { Stable, neurologically and by } \\
\text { imaging } 8 \text { months post- } \\
\text { biopsy; stable neurologically } \\
\text { one and a half months } \\
\text { post-biopsy }\end{array}$ \\
\hline 6 & $49 / M$ & $\begin{array}{l}\text { History of Lhermitte } \\
\text { sign and optic neuritis. } \\
\text { Diagnosed with multiple } \\
\text { sclerosis }\end{array}$ & $\begin{array}{l}\text { Multiple white matter } \\
\text { enhancing lesions, some } \\
\text { periventricular, with } \\
\text { dominant } 3 \mathrm{~cm} \mathrm{~L} \\
\text { frontal mass }\end{array}$ & $\begin{array}{l}\text { Bilateral periventricular } \\
\text { white matter }\end{array}$ & $\begin{array}{l}\mathrm{L} \text { frontal lobe and } \\
\text { dural biopsy }\end{array}$ & $\begin{array}{l}\text { Treated with } \\
\text { methotrexate } \\
\text { and fludarabine } \\
\text { with partial } \\
\text { response }\end{array}$ & $\begin{array}{l}\text { Negative } C T \text { chest } \\
\text { and abdomen }\end{array}$ & $\begin{array}{l}\text { Neurologically stable } 14 \\
\text { months post-biopsy } \\
\text { Family history of Alexander } \\
\text { disease }\end{array}$ \\
\hline 7 & $31 / \mathrm{F}$ & $\begin{array}{l}\text { Recurrent spells of } \\
\text { aphasia and right-sided } \\
\text { weakness for } 2 \text { years }\end{array}$ & $\begin{array}{l}\text { Multiple enhancing lesions, } \\
\text { predominantly white matter, }\end{array}$ & Bilateral white matter & $\begin{array}{l}\text { Stereotactic } \\
\text { biopsies } \times 2\end{array}$ & Steroids & $\begin{array}{l}\text { Negative bone } \\
\text { marrow biopsy } \\
\text { fat aspirate. }\end{array}$ & $\begin{array}{l}\text { Slight improvement in ima- } \\
\text { ging findings } 17 \text { months } \\
\text { post-biopsy }\end{array}$ \\
\hline
\end{tabular}


Table 1 Continued

\begin{tabular}{|c|c|c|c|c|c|c|c|c|}
\hline Patient & Age/sex & Clinical history & Imaging & Location & Surgery & Treatment & Systemic work-up & Follow-up \\
\hline & & & $\begin{array}{l}\text { involving left hemisphere } \\
\text { and cerebellum }\end{array}$ & & & & $\begin{array}{l}\text { Negative Body CT } \\
\text { and MRI of spine. } \\
\text { Normal serum and } \\
\text { urine electrophoresis } \\
\text { Elevated } \kappa / \lambda \text { ratio in } \\
\text { CSF (3.79) }\end{array}$ & \\
\hline 8 & $40 / F$ & $\begin{array}{l}\text { Transient R sided weak- } \\
\text { ness } 3 \text { years prior; multi- } \\
\text { focal muscle aches of } \\
\text { unclear etiology }\end{array}$ & $\begin{array}{l}\text { 'L temporal lobe AVM' } \\
\text { Stellate enhancement and T2 } \\
\text { abnormality in deep white matter } \\
\text { of } \mathrm{R} \text { frontal lobe }\end{array}$ & Bilateral, multifocal & $\begin{array}{l}\mathrm{L} \text { temporal lobe } \\
\text { stereotactic biopsy }\end{array}$ & $\begin{array}{l}\text { Alkeran and } \\
\text { prednisone } \\
\times 5 \text { cycles }\end{array}$ & $\begin{array}{l}\text { Normal bone mar- } \\
\text { row biopsy and fat } \\
\text { aspirate } \\
\text { Normal serum and } \\
\text { urine electrophoresis }\end{array}$ & $\begin{array}{l}\text { Persistent seizure disorder; } \\
\text { stable lesions on subsequent } \\
\text { studies but most recent MRI } \\
9 \text { years after first biopsy } \\
\text { shows new lesions of po- } \\
\text { tential concern }\end{array}$ \\
\hline 9 & $58 / F$ & $\begin{array}{l}\text { Weakness, nausea, vo- } \\
\text { miting, changes in men- } \\
\text { tal status }\end{array}$ & $\begin{array}{l}\text { MRI: multiple, ovoid, non-enhan- } \\
\text { cing lesions in cerebral and cer- } \\
\text { ebellar white matter }\end{array}$ & Bilateral white matter & $\begin{array}{l}\text { 1-R frontal lobe } \\
\text { biopsy } \\
\text { 2-Autopsy }\end{array}$ & $\begin{array}{l}\text { Rituximab, } \\
\text { high-dose steroids, } \\
\text { plasmapharesis }\end{array}$ & $\begin{array}{l}\text { CT of abdomen: } \\
\text { splenomegaly } \\
\text { Serum electrophor- } \\
\text { esis: monoclonal } \\
\kappa \text {-light chains } \\
\text { Bone marrow biopsy: } \\
\text { B-cell lymphoma } \\
\text { Autopsy: splenic } \\
\text { marginal } \\
\text { zone lymphoma }\end{array}$ & $\begin{array}{l}\text { DOD } 30 \text { days after onset of } \\
\text { symptoms }\end{array}$ \\
\hline 10 & $72 / F$ & Tinnitus & $\begin{array}{l}\text { CT: densely enhancing } \\
\text { mass lesion deep in the white } \\
\text { matter adjacent to the occipital } \\
\text { horn of the } R \text { ventricle }\end{array}$ & $\mathrm{R}$ parietal lobe & Biopsy & NA & NA & Lost to follow-up \\
\hline 11 & $70 / F$ & NA & NA & $\mathrm{R}$ parietal lobe & Biopsy & NA & NA & $\begin{array}{l}\text { Neurologically stable } 3 \\
\text { months post-biopsy }\end{array}$ \\
\hline 12 & $62 / M$ & $\begin{array}{l}\mathrm{L} \text { leg weakness and } \\
\text { paresthesias starting } \\
\text { approximately } 8 \text { years } \\
\text { prior }\end{array}$ & $\begin{array}{l}\text { MRI: enlargement through time } \\
\text { with mild enhancement }\end{array}$ & $\begin{array}{l}\text { S1, S2 nerve roots extending } \\
\text { into sciatic nerve }\end{array}$ & Fascicular biopsy & Observation & $\begin{array}{l}\text { Bone marrow } \\
\text { biopsy, fat aspirate, } \\
\text { and free light chains } \\
\text { in serum and urine } \\
\text { negative. }\end{array}$ & Stable 1 year post-biopsy \\
\hline 13 & $34 / F$ & $\begin{array}{l}\text { 'Stroke' followed by } \\
\text { seizure } 1 \text { month prior }\end{array}$ & MRI: 'tumor' & $L$ frontal dura & $\begin{array}{l}\text { Resection, followed } \\
\text { by open biopsies } 3 \\
\text { and } 12 \text { months after }\end{array}$ & NA & NA & $\begin{array}{l}\text { Developed nodular en- } \\
\text { hancement in right parietal } \\
\text { and occipital (extra axial) } \\
\text { regions prompting the third } \\
\text { biopsy }\end{array}$ \\
\hline
\end{tabular}


years (range, 31-72). Radiologic studies demonstrated multifocal lesions in the majority of the cases, usually involving cerebral white matter $(n=6)$. A single abnormality/ mass was present in five cases. In the single case involving peripheral nerve, a localized enhancing enlargement of the sciatic nerve was evident. No imaging data were available for the remaining case.

\section{Pathology}

Histologically, the proteinaceous deposits could be placed within one of the following categories: extracellular proteinaceous deposit not otherwise specified (PDNOS; $n=6$ ), amyloidoma $(n=5)$, or intracellular crystals $(n=2)$. The pathologic features are summarized in Table 2.

\section{Extracellular proteinaceous deposit not otherwise specified} These consisted of amorphous, flocculent, CR-negative extracellular eosinophilic proteinaceous aggregates with occasional calcification. In two cases well-formed extracellular crystals were also present. Two cases were associated with a contiguous low-grade B-cell lymphoma with lymphoplasmacytic differentiation and demonstrated a foreign body giant cell reaction to the deposits (Figure 1). A marginal zone lymphoma of the spleen was identified at autopsy in one dramatic case characterized by deeply eosinophilic immunoglobulin lakes mostly in white matter but with smaller aggregates in the cortex (Figure 2).

\section{Amyloidoma}

Amorphous pink aggregates of amyloid were present in a parenchymal and/or perivascular pattern (Figure 3a). CR staining was positive in all cases, showing strong red fluorescence (Figure $3 \mathrm{~b}$ and c). An associated mild, generally perivascular lymphoplasmacytic infiltrate was also identified.

\section{Intracellular crystals}

Intracellular crystals were the hallmark in two cases. In case 7, there was a massive intracellular accumulation of needle shaped to rhomboid crystals within CD68 + macrophages throughout the biopsy consistent with intracerebral crystalstoring histiocytosis (Figure 4). Scattered, mostly perivascular plasma cells were present. In case 2, thicker rhomboid crystals were noted within CD138 + plasma cells, which were less frequent than in case 7. 'Touton-like' multinucleated giant cells were also present.

\section{Mass Spectrometry and Immunohistochemistry}

Proteomic analyses provided reliable MS and MS/MS spectra in a representative case (Figure 5), and the Scaffold ${ }^{\mathrm{TM}}$ search algorithm provided reproducible protein profiles in all 13 cases tested (Supplementary Data).

\section{Extracellular proteinaceous deposit not otherwise specified}

Interestingly, the non-amyloid extracellular depositions contained $\kappa$-light chains, but not $\lambda$, in most cases $(n=5)$.
One case contained $\kappa$ - as well as $\lambda$-light chains. Additional proteins identified included immunoglobulin (Ig) $\mathrm{G}(n=5)$, $\operatorname{IgM}(n=2), \operatorname{IgA}(n=2), \operatorname{IgJ}(n=2)$, apolipoprotein A-I (ApoA-I) $(n=3)$, and ApoE $(n=2)$. Ig heavy chain, ApoA-II, and C9 were identified in single cases each. Immunohistochemistry with $\kappa$ - and $\lambda$-light chain confirmed $\kappa$-light chain restriction in four cases, either in the deposits $(n=3)$ and/or the inflammatory infiltrate $(n=2)$. A polytypic pattern of light-chain expression by immunohistochemistry was present in the single case demonstrating both $\kappa$ - and $\lambda$-light-chain peptides by LC-MS/MS. In addition, one (of two) cases with IgM showed convincing immunostaining (Figure 2).

\section{Amyloidomas}

$\lambda$-Light chains, SAP, ApoE, and ApoA-IV were identified in all cases $(n=5)$. In addition, ApoA-I was identified in three cases, and IgG and IgA in single cases each. Immunohistochemistry demonstrated $\lambda$ (but not $\kappa$ ) light chains in the aggregates in all cases, and SAP in two (of three) cases tested.

\section{Intracellular crystals}

The example consistent with crystal-storing histiocytosis (case 7) demonstrated $\kappa$-light chain as well as a minor GFAP component on LC-MS/MS. The GFAP was likely secondary to the presence of underlying brain tissue/reactive astrocytes in the microdissected area. Immunostains for $\kappa$ - and $\lambda$-light chains were non-contributory secondary to ample background staining. However, in situ hybridization labeled monotypic $\kappa$-plasma cells (Figure 4). Conversely, in case 2, IgG was identified by LC-MS/MS. The crystals demonstrated reactivity with $\operatorname{IgG}$ and $\lambda$-light chains, but not $\kappa$, antibodies by immunohistochemistry.

\section{DISCUSSION}

Protein characterization in tissue samples is an active field that has generated much excitement in recent years. Protein analysis focused on identification of single proteins or peptides has been most extensively explored in serum using gel electrophoresis/western blotting or immunoassays, such as ELISA. ${ }^{11,12}$ However, some of these commonly used assays are limited in their sensitivity, require relatively large amounts of sample, and focus on only a small number of proteins. These traditional methods have also been successfully applied to cell lines and fresh or frozen tissue for protein analyses, but are not applicable to FFPE tissues.

Immunohistochemistry is a technique that has been studied and extensively applied for protein identification in diagnostic pathology and research. Although presently it is the most widely applied technique to study protein expression in FFPE archival material, immunostaining of extracellular protein deposits is problematic as antigenic epitopes are often lost in the tertiary structure of the deposit, and contamination from serum proteins often gives rise to marked background that yields indeterminate results. Formal 
Table 2 Protein deposits in clinical specimens of the nervous system: pathologic features

\begin{tabular}{|c|c|c|c|c|c|}
\hline Patient & Diagnosis & Histopathology & Congo red & Immunohistochemistry & Mass spectrometry \\
\hline 1 & Amyloidoma & $\begin{array}{l}\text { Eosinophilic parenchymal } \\
\text { and vascular aggregates } \\
\text { with focal giant cell } \\
\text { reaction associated with } \\
\text { perivascular plasma cell } \\
\text { proliferation }\end{array}$ & Positive & $\begin{array}{l}\lambda \text {-Light chain positivity in } \\
\text { deposits and plasma cells } \\
\text { SAP+ } \\
\text { SAA-, Transthyretin-, } \\
\beta \text {-microglobulin- }\end{array}$ & $\begin{array}{l}\lambda, \text { ApoE, Apo-AIV, and } \\
\text { SAP peptides }\end{array}$ \\
\hline 2 & $\begin{array}{l}\text { Neoplasm with } \\
\text { extensive plasma } \\
\text { cell differentiation }\end{array}$ & $\begin{array}{l}\text { Prominent } \\
\text { intracytoplasmic } \\
\text { immunoglobulin rhomboid/ } \\
\text { rectangular crystals in } \\
\text { plasma cells; rare Touton- } \\
\text { like multinucleated giant } \\
\text { cells; perivascular } \\
\text { inflammation }\end{array}$ & Negative & $\begin{array}{l}\text { Perivascular mixture of } \\
\text { CD3 and CD20+ T- and } \\
\text { B-cells CD138+ plasma } \\
\text { cells, } \lambda \text {-lg light chain. } \\
\text { Crystals lgG+ }\end{array}$ & IgG peptide \\
\hline 3 & $\begin{array}{l}\text { Low-grade B-cell } \\
\text { lymphoma with } \\
\text { plasmacytic dif- } \\
\text { ferentiation }\end{array}$ & $\begin{array}{l}\text { Flocculent extracellular } \\
\text { proteinaceous deposit with } \\
\text { occasional giant cell } \\
\text { reaction, lymphoplasmacytic } \\
\text { infiltrate mainly } \\
\text { perivascular }\end{array}$ & Negative & $\begin{array}{l}\kappa \text {-Light-chain-restricted } \\
\text { lymphoplasmacytic cells. } \\
\text { Predominant CD20+ } \\
\text { B-cells with a minor } \\
\text { CD138+ plasma cell } \\
\text { component }\end{array}$ & $\begin{array}{l}\kappa, \operatorname{lgG}, \text { and } A p o E \\
\text { peptides }\end{array}$ \\
\hline 4 & $\begin{array}{l}1 \text { Amorphous } \\
\text { debris } \\
2 \text { Old organized } \\
\text { intraparenchymal } \\
\text { cystic lesion with } \\
\text { proteinaceous } \\
\text { content }\end{array}$ & $\begin{array}{l}\text { Amorphous eosinophilic } \\
\text { debris with dystrophic } \\
\text { calcifications, focal } \\
\text { crystalline appearance, } \\
\text { no inflammation }\end{array}$ & Negative & inconclusive & $\begin{array}{l}\kappa, \lg G \text {, and } \lg A \text { pep- } \\
\text { tides }\end{array}$ \\
\hline 5 & Amyloidoma & $\begin{array}{l}\text { Parenchymal and perivas- } \\
\text { cular involvement; Scant } \\
\text { perivascular lymphoplasma- } \\
\text { cytic infiltrate }\end{array}$ & Positive & $\begin{array}{l}\lambda+\text { Aggregates, paren- } \\
\text { chymal and vessel walls; } \\
\text { SAP focal+ } \\
\text { SAA-, } \beta \text {-microglobulin-, } \\
\beta \text {-amyloid- }\end{array}$ & $\begin{array}{l}\lambda, \text { ApoE, Apo-AIV, and } \\
\text { SAP peptides }\end{array}$ \\
\hline 6 & $\begin{array}{l}\text { Extranodal mar- } \\
\text { ginal zone lym- } \\
\text { phoma }\end{array}$ & $\begin{array}{l}\text { Granulomatous reaction to } \\
\text { extracellular crystalline } \\
\text { immunoglobulin }\end{array}$ & Negative & $\begin{array}{l}\kappa \text {-Restricted B-cells, plasma } \\
\text { cells, and extracellular } \\
\text { crystals; IgM+ cells, } \\
\text { aggregates-; IgA-, lgG } \\
\text { non-contributory }\end{array}$ & $\kappa$ and $\operatorname{lgG}$ peptides \\
\hline 7 & $\begin{array}{l}\text { Atypical plasma } \\
\text { cell infiltrate sus- } \\
\text { picious for plasma } \\
\text { cell proliferative } \\
\text { disorder and } \\
\text { crystal storing } \\
\text { histiocytosis }\end{array}$ & $\begin{array}{l}\text { Histiocytes engorged with } \\
\text { crystals, scant perivascular } \\
\text { plasma cells }\end{array}$ & ND & $\begin{array}{l}\text { Small groups of } \kappa \text {-re- } \\
\text { stricted plasma cells by } \\
\text { in situ hybridization } \\
\text { Cells with crystals are } \\
\text { CD68+histiocytes } \\
\text { Immunostains for } \kappa \text { and } \lambda \\
\text { non-contributory }\end{array}$ & $\kappa$ and GFAP peptides \\
\hline
\end{tabular}


Table 2 Continued

\begin{tabular}{|c|c|c|c|c|c|}
\hline Patient & Diagnosis & Histopathology & Congo red & Immunohistochemistry & Mass spectrometry \\
\hline 8 & Amyloidoma & $\begin{array}{l}\text { Eosinophilic parenchymal } \\
\text { and vascular } \\
\text { aggregates; } \\
\text { reactive gliosis }\end{array}$ & Positive & $\begin{array}{l}\lambda+ \\
\text { Rare CD20+ B-cells and } \\
\text { CD138+ plasma cells }\end{array}$ & $\begin{array}{l}\lambda, \text { SAP, ApoE, Apo-Al, } \\
\text { and Apo-AIV peptides }\end{array}$ \\
\hline 9 & $\begin{array}{l}\text { Extracellular pro- } \\
\text { teinaceous de- } \\
\text { posits in brain; } \\
\text { marginal zone } \\
\text { lymphoma of } \\
\text { spleen }\end{array}$ & $\begin{array}{l}\text { Large eosinophilic } \\
\text { proteinaceous } \\
\text { aggregates; no } \\
\text { inflammation }\end{array}$ & Negative & $\begin{array}{l}\kappa+, \lg \mathrm{M}_{+} \\
\lg \mathrm{A}-, \lg \mathrm{G}-\end{array}$ & $\begin{array}{l}\kappa, \operatorname{lgM}, \text { Apo-Al, and } \\
\text { lgJ peptides }\end{array}$ \\
\hline 10 & Amyloidoma & $\begin{array}{l}\text { Parenchymal and } \\
\text { perivascular, gliosis, } \\
\text { no inflammation }\end{array}$ & Positive & $\begin{array}{l}\lambda \text {-Free light chain }+; \kappa-\text {, } \\
\text { SAA-, prealbumin }-, \\
\text { SAP- }\end{array}$ & $\begin{array}{l}\lambda, \text { SAP, IgG, IgA, ApoE, } \\
\text { and Apo-AIV, and } \\
\text { Apo-Al peptides }\end{array}$ \\
\hline 11 & $\begin{array}{l}\text { Proteinaceous } \\
\text { deposition }\end{array}$ & $\begin{array}{l}\text { Extracellular eosinophilic } \\
\text { proteinaceous pools } \\
\text { surrounded by } \\
\text { lymphoplasmacytic } \\
\text { infiltrate with eosinophils, } \\
\text { collagen deposition }\end{array}$ & Negative & $\begin{array}{l}\kappa+\text { deposition, } \lg \mathrm{A}, \lg \mathrm{G}, \\
\text { and } \lg \mathrm{M} \text { equivocal }\end{array}$ & $\begin{array}{l}\kappa, \operatorname{lgA}, \operatorname{lgG}, \text { Apo-Al, } \\
\text { Apo-All, and IgJ pep- } \\
\text { tides }\end{array}$ \\
\hline 12 & Amyloidoma & $\begin{array}{l}\text { Tumefactive mass of } \\
\text { amyloid replacing a } \\
\text { nerve fascicle. } \\
\text { Mild perivascular } \\
\text { lymphocytic infiltrate } \\
\text { in adjacent tissue }\end{array}$ & Positive & $\lambda+$ & $\begin{array}{l}\lambda, \text { SAP, ApoE, Apo-Al, } \\
\text { and Apo-AlV peptides }\end{array}$ \\
\hline 13 & $\begin{array}{l}\text { Chronic } \\
\text { inflammation } \\
\text { with eosinophils }\end{array}$ & $\begin{array}{l}\text { Mixed lymphoplasmacytic } \\
\text { infiltrate with eosinophils, } \\
\text { eosinophilic amorphous } \\
\text { material, fibrosis }\end{array}$ & Negative & Polytypic plasma cells & $\begin{array}{l}\lambda, \kappa, A p o E, \lg G \text {, lgM, } \\
C 9, \text { ApoA1, lg heavy } \\
\text { chain }\end{array}$ \\
\hline
\end{tabular}

NA, information not available; ND, not done; SAP, serum amyloid protein; Ig, immunoglobulin.

doubts have been raised about the reliability of immunohistochemistry in determining the amyloidosis type. ${ }^{13}$ Furthermore, these studies are limited by the small number of markers that can be simultaneously studied in a single tissue section, as well as the variety and number of commercial antibodies available. Of the methods discussed, only immunohistochemistry has been extensively used in the study of FFPE tissue. Although FFPE is the primary archival form of pathologic specimens, and permits retrospective study of numerous samples with clinical follow-up, the extension of high throughput analyses to this resource should yield a wealth of biologic information.
With the advent of proteomics, newer technologies have emerged that bypass all these limitations. In addition to its promise as a powerful diagnostic technique that is the subject of the current study, MS may be considered at the present time the technique with the greatest potential for unbiased biomarker discovery, as well as significantly aiding in our understanding of disease pathogenesis. ${ }^{14}$ High throughput platforms that utilize MS have been successfully applied to serum peptide profiling. Examples include its application to glioblastoma, ${ }^{15}$ as well as ovarian ${ }^{16}$ and prostate carcinoma. ${ }^{17}$ Other applications include mapping of plasma membrane proteins in brain ${ }^{18}$ and the detection of DNA-mismatch 

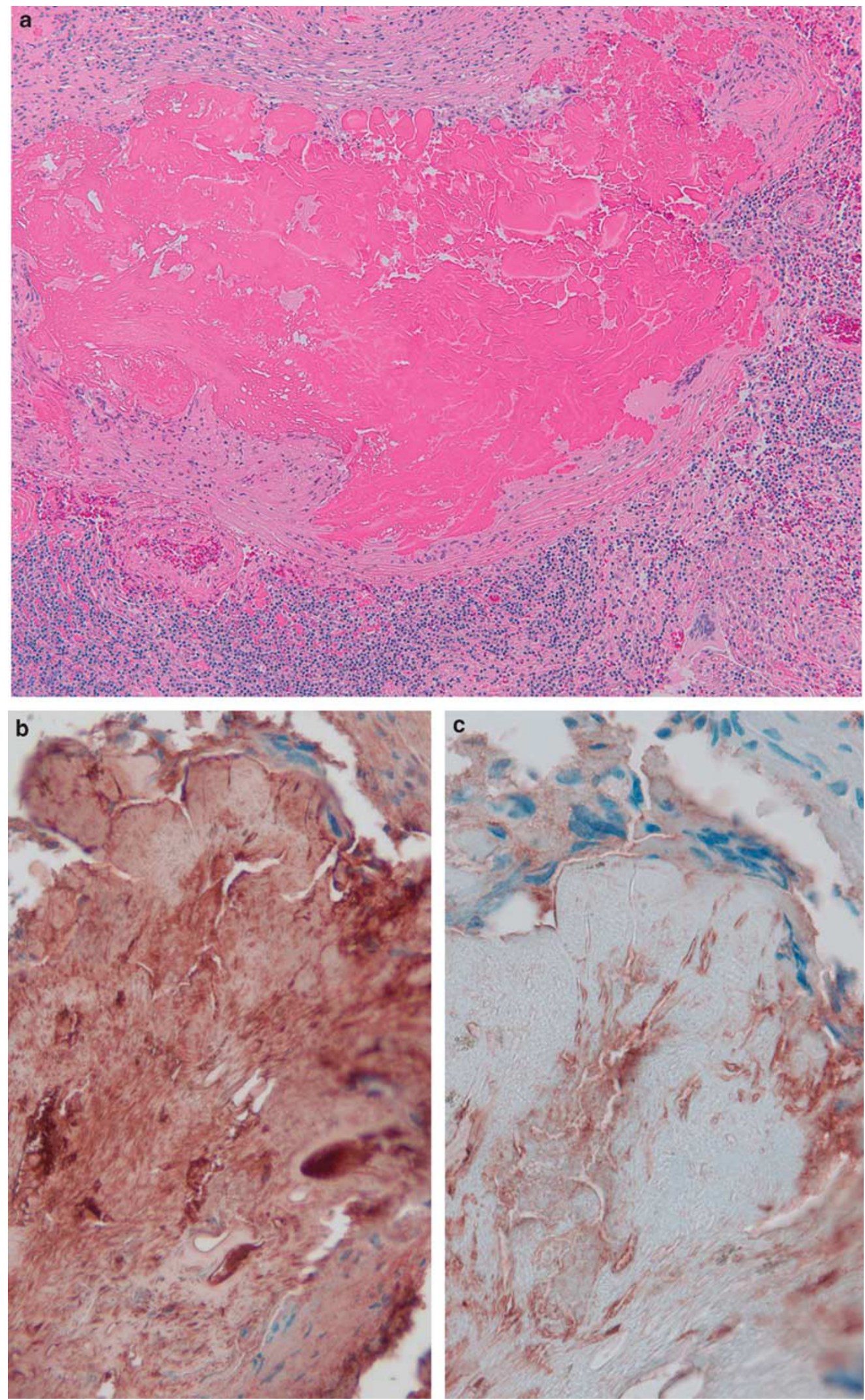

Figure 1 Extracellular proteinaceous deposition with crystals (case 6). Aggregates of eosinophilic proteinaceous deposits with crystal formation are surrounded by a dense neoplastic lymphoplasmacytic infiltrate (a). Immunohistochemical stains demonstrate $\kappa$-light chain (b) immunostaining but absent $\lambda$ (c) consistent with $\kappa$-light-chain restriction. The latter was also demonstrated by mass spectrometry, which in addition revealed Ig- $\gamma$ and Ig heavy chain peptides (not shown). 

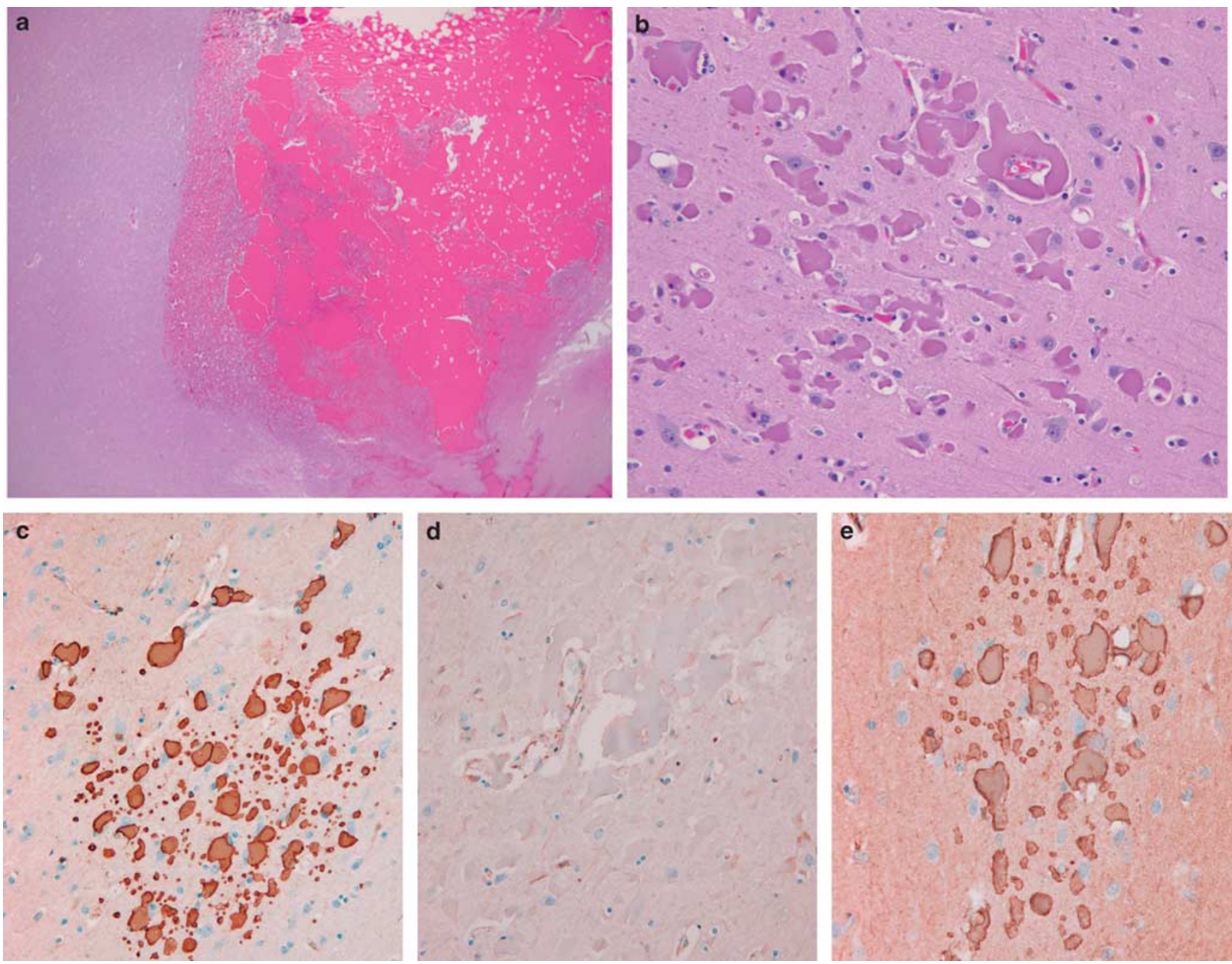

Figure 2 Extracellular proteinaceous deposition in the brain in a case of splenic marginal zone lymphoma. Lakes of eosinophilic deposits lacking crystals are involving predominantly white matter (a), although scant smaller deposits are also present in gray matter (b). Immunohistochemical stains demonstrate $\kappa$-light-chain expression (c) but not $\lambda(\mathbf{d})$, as well as $\operatorname{lgM}(\mathbf{e})$.

repair-deficient cells. ${ }^{19}$ Combining MS with immunoaffinity enrichment has also been successful in identifying chromosomal translocation partners in anaplastic lymphoma. ${ }^{20}$

Traditionally, the application of proteomics to FFPE has been limited by several factors, including the crosslinks induced by formaldehyde and alterations secondary to the embedding process that affects protein solubility. However, some authors have been successful in extending proteomic analyses to these tissues with appropriate methods that involve proteolytic cleavage, ${ }^{21-23}$ including in situ enzymatic digestion and even matrix-assisted laser desorption/ionization $\mathrm{MS},{ }^{24}$ which allows for delineation of the spatial distribution of proteins. A proteomic-based approach to surgically obtained samples complements the study of gene expression profiling, given the greater susceptibility of RNA for degradation, as well as the possibility to study posttranslational modifications ${ }^{25}$ difficult to investigate with traditional genomics.
We hypothesized that the application of MS to protein analysis may not be restricted to proteomic research, but that it may also be of use in diagnostic surgical pathology. We have found that sample digestion with separation of peptide mixtures by chromatography followed by analysis in a modern hybrid mass spectrometer produces accurate information about the composition of complex samples and is feasible to perform in archival material. Laser microdissection, a technique with numerous applications in molecular analysis, ${ }^{26,27}$ enhances diagnostic precision in this setting. A probability-based algorithm and comparison with available databases greatly simplifies and increases the efficiency of protein characterization. ${ }^{28}$

In our experience, proteinaceous deposits encountered in biopsies of the nervous system often represent diagnostic challenges even after a thorough clinicopathologic work-up. Among these, amyloidomas have been best characterized, although it is known that other forms of light-chain-derived 

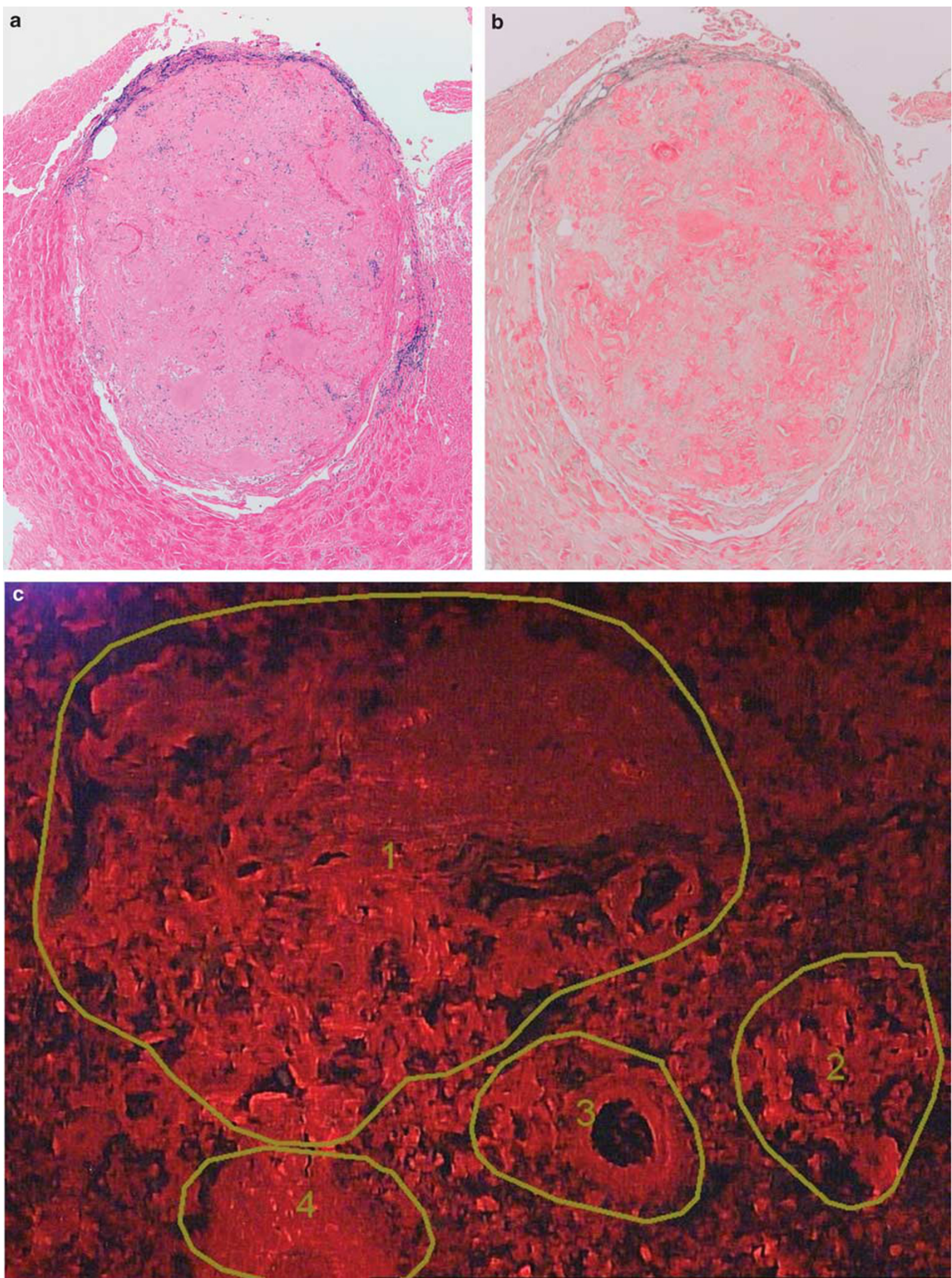

Figure 3 Amyloidoma of sciatic nerve and laser microdissection (case 12). Localized tumefactive amyloid deposit replacing a peripheral nerve fascicle demonstrated on H\&E (a) and Congo red (b) stains. Rhodamine optics demonstrates bright red fluorescence (c, Congo red). Several areas are traced in the computer screen, microdissected and submitted for analysis using available software. $\lambda$-Light-chain restriction was demonstrated by immunohistochemistry and mass spectrometry (not shown). 

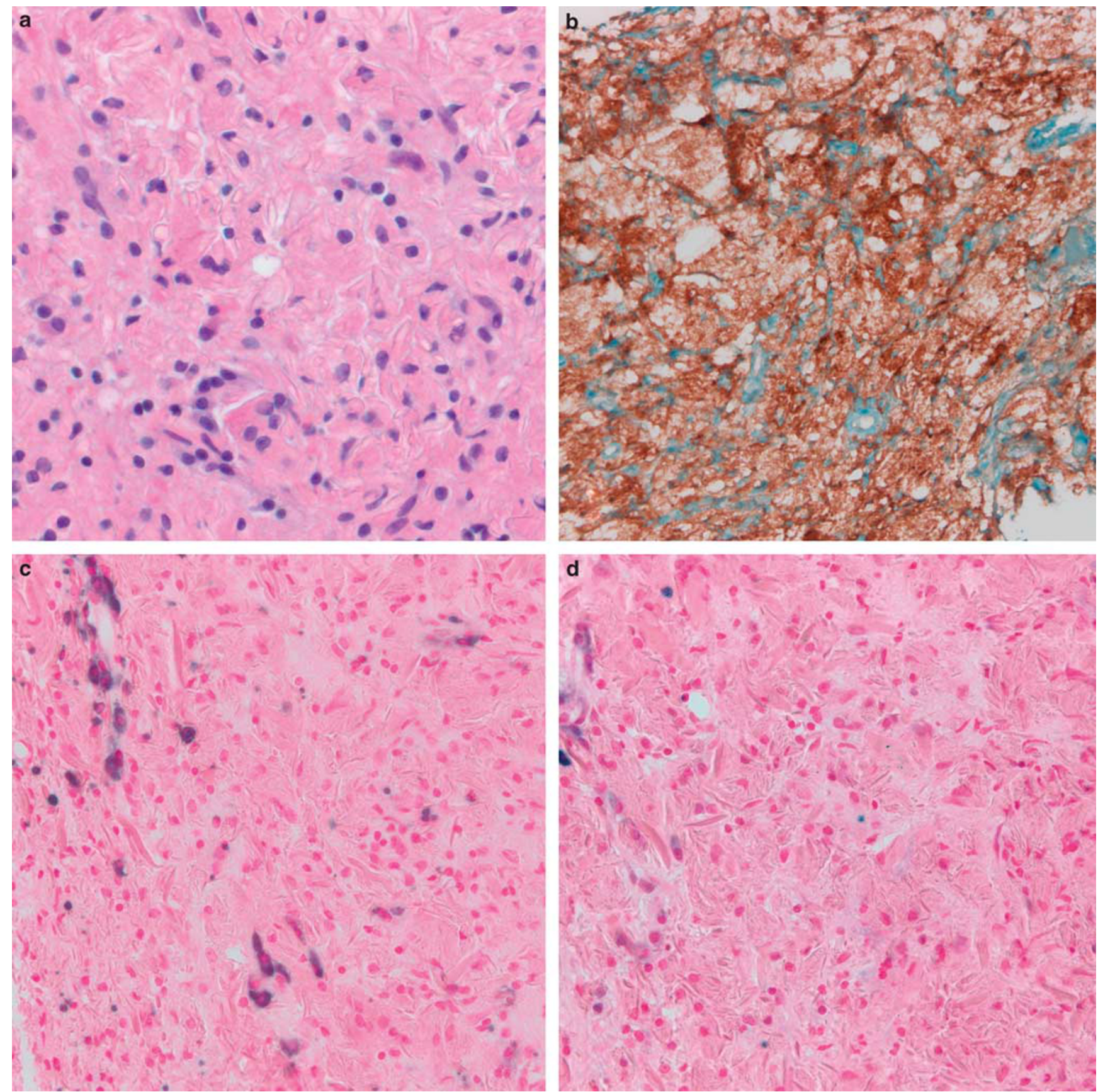

Figure 4 Crystal-storing histiocytosis (case 7). Intracellular refractile crystals are evident on H\&E stain (a). The histiocytic nature of the cells is confirmed by strong CD68 expression (b). In situ hybridization demonstrates $\kappa$ mRNA (but not $\lambda$ ) focally in perivascular plasma cells (c and $\mathbf{d}$, respectively).

deposits that lack the ultrastructural and histochemical properties of amyloid may deposit systemically as in lightchain deposition disease, ${ }^{6}$ or in the form of tumefactive masses. ${ }^{29,30}$ Systemic light-chain deposition disease ${ }^{31}$ as well as reported tumefactive extraneural aggregates thereof ${ }^{29,30}$ and crystal-storing histiocytosis ${ }^{7-9}$ shows a tendency to $\kappa$-light-chain restriction. It is of interest that two previously reported cases of light-chain deposition disease involving the brain were $\lambda$-light chain derived, ${ }^{32,33}$ unlike our cases in which non-amyloid deposits were mostly $\kappa$. Of note neither of those two previously reported cases was evaluated by MS. Our present study extends the use of MS to the characterization of these deposits in FFPE. There was an excellent concordance with immunohistochemical results, although MS confirmed light-chain restriction and the nature of intracellular deposits in at least one case with noncontributory immunostaining.

A point of practical importance involves the concurrence of a lymphoplasmacytic proliferation with a specific type of protein deposit. In cases with amyloid deposition, as those 
a ImmunostainsISD154s3 \#2464 RT: 38.24 AV: 1 NL: 1.11E7 T: FTMS + p NSI Full ms [375.00-1600.00]
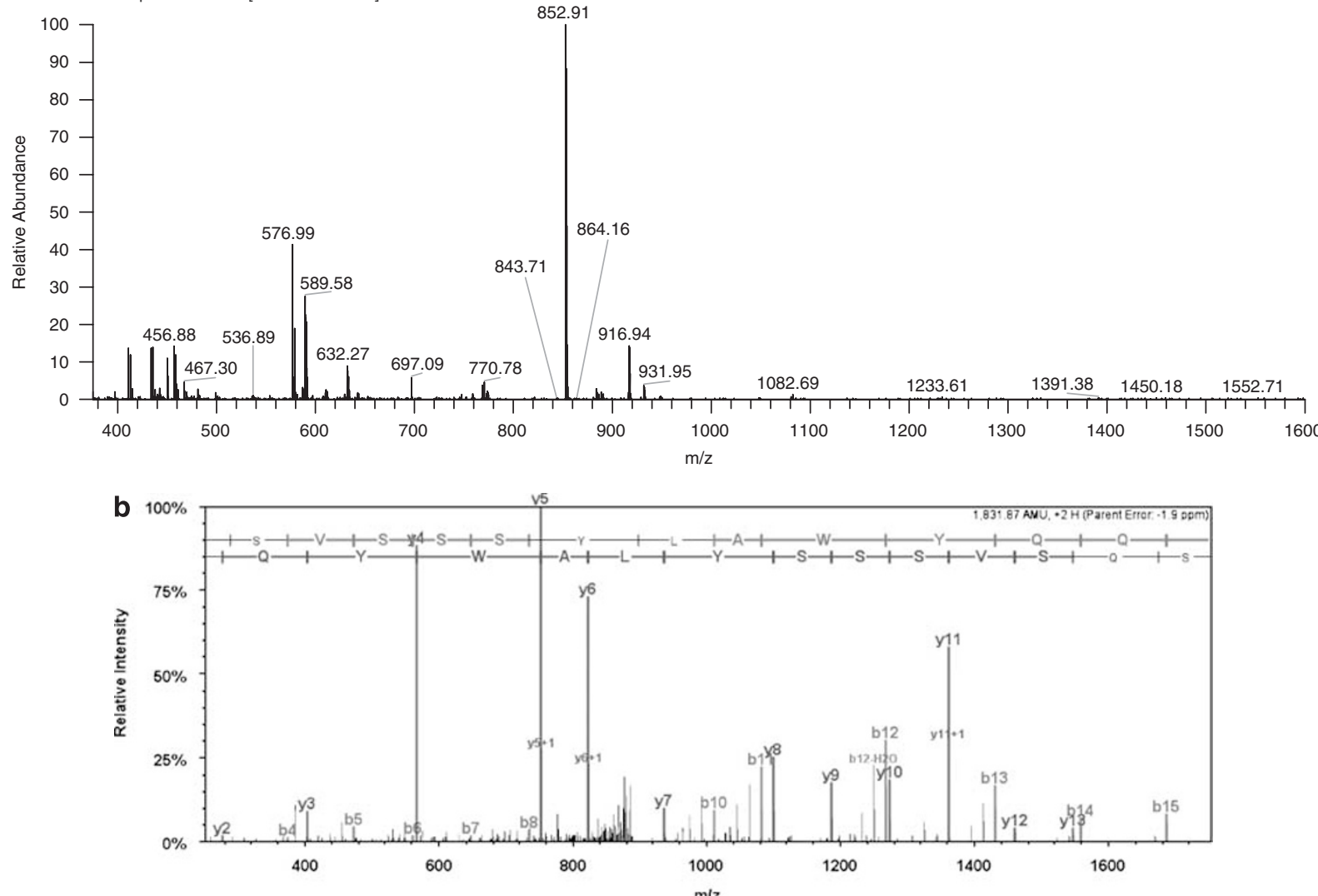

\begin{tabular}{|c|c|c|c|c|c|c|c|c|c|c|}
\hline$B$ & B Ions & $\mathrm{B}+2 \mathrm{H}$ & B-NH3 & $\mathrm{B}-\mathrm{H} 2 \mathrm{O}$ & AA & $\gamma$ Ions & $\mathrm{Y}+2 \mathrm{H}$ & $\mathrm{Y}-\mathrm{NH} 3$ & $\mathrm{Y}-\mathrm{H} 2 \mathrm{O}$ & $\gamma$ \\
\hline 1 & 72.0 & & & & A & $1,832.9$ & 916.9 & $1,815.9$ & $1,814.9$ & 16 \\
\hline 2 & 159.1 & & & 141.1 & 5 & $1,761.8$ & 881.4 & $1,744.8$ & $1,743.8$ & 15 \\
\hline 3 & 287.1 & & 270.1 & 269.1 & Q & $1,674.8$ & 837.9 & $1,657.8$ & $1,656.8$ & 14 \\
\hline 4 & 374.2 & & 357.1 & 356.2 & 5 & $1,546.8$ & 773.9 & $1,529.7$ & $1,528.7$ & 13 \\
\hline 5 & 473.2 & & 456.2 & 455.2 & $\gamma$ & 1.459 .7 & 730.4 & $1,442.7$ & $1,441.7$ & 12 \\
\hline 6 & 560.3 & 280.6 & 543.2 & 542.3 & 5 & $1,360.7$ & 680.8 & 1.343 .6 & $1,342.6$ & 11 \\
\hline 7 & 647.3 & 324.2 & 630.3 & 629.3 & 5 & 1.273 .6 & 637.3 & 1.256 .6 & $1,255.6$ & 10 \\
\hline 8 & 734.3 & 367.7 & 717.3 & 716.3 & 5 & 1.186 .6 & 593.8 & 1.169 .6 & $1,168.6$ & 9 \\
\hline 9 & 897.4 & 449.2 & 880.4 & 879.4 & $Y$ & 1.099 .6 & 550.3 & $1,082.5$ & & 8 \\
\hline 10 & 1.010 .5 & 505.7 & 993.5 & 992.5 & L & 936.5 & 468.8 & 919.5 & & 7 \\
\hline 11 & 1.081 .5 & 541.3 & 1.064 .5 & 1.063 .5 & A & 823.4 & 412.2 & 806.4 & & 6 \\
\hline 12 & 1.267 .6 & 634.3 & 1.250 .6 & 1.249 .6 & $w$ & 752.4 & & 735.3 & & 5 \\
\hline 13 & 1.430 .7 & 715.8 & 1.413 .6 & 1.412 .6 & $Y$ & 566.3 & & 549.3 & & 4 \\
\hline 14 & 1.558 .7 & 779.9 & 1.541 .7 & 1.540 .7 & $\mathbf{Q}$ & 403.2 & & 386.2 & & 3 \\
\hline 15 & 1.686 .8 & 843.9 & 1.669 .7 & $1,668.8$ & $\mathbf{Q}$ & 275.2 & & 258.1 & & 2 \\
\hline 16 & $1,832.9$ & 916.9 & $1,815.9$ & $1,814.9$ & $K$ & 147.1 & & 130.1 & & 1 \\
\hline
\end{tabular}

C KV312_HUMAN (95\%), 14,073.5 Da Ig kappa chain V-III region HAH precursor - Homo sapiens (Human) (P18135)
$M E T P A Q L L F L$
L L LWLPDT T G
LSLSPGERAT
LSCRASQSVS
E I VLTQSPG T
$P G Q A P R L L \mid Y$
$G A S S R A T G$ I P
S S Y L A W Y Q Q K
D F T L T I S R L E
PEDFAVYYCQ $Q Y$ Q
Q G T K VE I KR
Parent Mass +1831.8704 , observed mass is 916.943 with $Z=2$,

Figure 5 Tandem mass spectrometry (MS) analysis identifies $\kappa$-light chain V-III in case 9 . The Orbitrap MS survey scan containing a parent ion mass of 916.943 Da is shown in (a). The LTQ MS/MS scan of the doubly charged ion at $916 \mathrm{Da}$ is shown in (b). A database search against the MS/MS spectra revealed this to be ASQSVSSYLAWYQQK with an XCorr of 5.14 and -1.9 p.p.m. mass error corresponding to Ig $\kappa$-light chain (KV312_HUMAN) (c). 
described in the literature, an associated lymphoproliferative disorder is not present, with the exception of extranodal marginal zone lymphoma of the dura. Conversely, in cases of PDNOS, a low-grade B-cell lymphoma with plasmacytic differentiation may be an identifiable etiology. As demonstrated in one of our patients with a splenic marginal zone lymphoma, the neoplastic process may not be evident in the brain lesion. Such cases require a careful systemic work-up and close follow-up to discover the neoplasm. The demonstration of non-amyloid proteinaceous deposits containing $\kappa$-light chain may, therefore, be of clinical and prognostic importance.

A further illustrative aspect of our study is that MS found these various protein deposits to be complex, including additional immunoglobulin and apolipoprotein-derived peptides. It is known that a variety of apolipoproteins including ApoA-I, ApoA-II, and ApoA-IV are amyloidogenic, a phenomenon that is enhanced by specific alleles. This has been studied in transgenic mice models. ${ }^{34}$ Several of these proteins were identified in our analyses. These proteins are not routinely evaluated on amyloid immunohistochemical panels. Although they seem to be involved in amyloid formation, it is unclear what their role is in non-amyloid deposits. Our limited study does not provide any mechanistic insights into pathogenesis, but future studies with a larger number of cases, and more detailed exploration of the significance of the various peptides identified, should further our current limited understanding of these disorders.

In summary, proteomics is beginning to have an important role, not only in research into human disease, but also in molecular diagnostics as well. The use of novel exquisitely sensitive and specific practical techniques, including MS, in the analysis of protein accumulations enhances the diagnostic precision afforded by routine histology and immunohistochemistry. We employed this technique in a focused study of immunoglobulin-derived deposits, but we believe in its potential to find widespread applications in diagnostic surgical pathology in addition to its betterpublicized role in biomarker discovery.

Supplementary Information accompanies the paper on the Laboratory Investigation website (http://www.laboratoryinvestigation.org)

\section{ACKNOWLEDGEMENT}

We thank the clinicians and pathologists who contributed follow-up information, as well as Peggy Chihak for technical assistance with illustrations.

1. Matsumoto $T$, Tani $E$, Fukami $M$, et al. Amyloidoma in the gasserian ganglion: case report. Surg Neurol 1999;52:600-603.

2. Laeng RH, Altermatt $\mathrm{HJ}$, Scheithauer BW, et al. Amyloidomas of the nervous system: a monoclonal B-cell disorder with monotypic amyloid light chain lambda amyloid production. Cancer 1998;82:362-374.

3. Bookland MJ, Bagley CA, Schwarz J, et al. Intracavernous trigeminal ganglion amyloidoma: case report. Neurosurgery 2007;60:E574; discussion E574.
4. Schroder R, Linke RP, Voges J, et al. Intracerebral A lambda amyloidoma diagnosed by stereotactic biopsy. Clin Neuropathol 1995; 14:347-350.

5. Lehman NL, Horoupian DS, Warnke RA, et al. Dural marginal zone lymphoma with massive amyloid deposition: rare low-grade primary central nervous system B-cell lymphoma. Case report. J Neurosurg 2002;96:368-372.

6. Randall RE, Williamson Jr WC, Mullinax $F$, et al. Manifestations of systemic light chain deposition. Am J Med 1976;60:293-299.

7. Lebeau A, Zeindl-Eberhart E, Muller EC, et al. Generalized crystalstoring histiocytosis associated with monoclonal gammopathy: molecular analysis of a disorder with rapid clinical course and review of the literature. Blood 2002;100:1817-1827.

8. Jones D, Bhatia VK, Krausz T, et al. Crystal-storing histiocytosis: a disorder occurring in plasmacytic tumors expressing immunoglobulin kappa light chain. Hum Pathol 1999;30:1441-1448.

9. Kusakabe T, Watanabe K, Mori T, et al. Crystal-storing histiocytosis associated with MALT lymphoma of the ocular adnexa: a case report with review of literature. Virchows Arch 2007;450:103-108.

10. Lentz D, Mason CJ, Chiarito R. Proteome Workflow: Workflow Tool for Building Proteomics Workflows, in 55th Annual American Society for Mass Spectrometry. American Society for Mass Spectrometry: Indianapolis, IN, USA, 2007.

11. Carr KM, Rosenblatt K, Petricoin EF, et al. Genomic and proteomic approaches for studying human cancer: prospects for true patienttailored therapy. Hum Genomics 2004;1:134-140.

12. Petricoin EF, Liotta LA. Mass spectrometry-based diagnostics: the upcoming revolution in disease detection. Clin Chem 2003;49: 533-534.

13. Solomon A, Murphy CL, Westermark P. Unreliability of immunohistochemistry for typing amyloid deposits. Arch Pathol Lab Med 2008;132:14.

14. Lim MS, Elenitoba-Johnson KS. Proteomics in pathology research. Lab Invest 2004;84:1227-1244.

15. Villanueva J, Philip J, Entenberg D, et al. Serum peptide profiling by magnetic particle-assisted, automated sample processing and MALDI-TOF mass spectrometry. Anal Chem 2004;76: 1560-1570.

16. Petricoin EF, Ardekani AM, Hitt BA, et al. Use of proteomic patterns in serum to identify ovarian cancer. Lancet 2002;359:572-577.

17. Merchant $M$, Weinberger SR. Recent advancements in surfaceenhanced laser desorption/ionization-time of flight-mass spectrometry. Electrophoresis 2000;21:1164-1177.

18. Olsen JV, Nielsen PA, Andersen JR, et al. Quantitative proteomic profiling of membrane proteins from the mouse brain cortex, hippocampus, and cerebellum using the HysTag reagent: mapping of neurotransmitter receptors and ion channels. Brain Res 2007;1134: 95-106.

19. Bonk T, Humeny A, Gebert J, et al. Matrix-assisted laser desorption/ ionization time-of-flight mass spectrometry-based detection of microsatellite instabilities in coding DNA sequences: a novel approach to identify DNA-mismatch repair-deficient cancer cells. Clin Chem 2003;49:552-561.

20. Elenitoba-Johnson KS, Crockett DK, Schumacher JA, et al. Proteomic identification of oncogenic chromosomal translocation partners encoding chimeric anaplastic lymphoma kinase fusion proteins. Proc Natl Acad Sci USA 2006;103:7402-7407.

21. Palmer-Toy DE, Krastins B, Sarracino DA, et al. Efficient method for the proteomic analysis of fixed and embedded tissues. J Proteome Res 2005;4:2404-2411.

22. Guo T, Wang W, Rudnick PA, et al. Proteome analysis of microdissected formalin-fixed and paraffin-embedded tissue specimens. J Histochem Cytochem 2007;55:763-772.

23. Crockett DK, Lin Z, Vaughn CP, et al. Identification of proteins from formalin-fixed paraffin-embedded cells by LC-MS/MS. Lab Invest 2005;85:1405-1415.

24. Lemaire R, Desmons A, Tabet JC, et al. Direct analysis and MALDI imaging of formalin-fixed, paraffin-embedded tissue sections. J Proteome Res 2007;6:1295-1305.

25. Schumacher JA, Crockett DK, Elenitoba-Johnson KS, et al. Evaluation of enrichment techniques for mass spectrometry: identification of tyrosine phosphoproteins in cancer cells. J Mol Diagn 2007;9: 169-177. 
26. Hood BL, Darfler MM, Guiel TG, et al. Proteomic analysis of formalin-fixed prostate cancer tissue. Mol Cell Proteomics 2005;4: 1741-1753.

27. Espina V, Wulfkuhle JD, Calvert VS, et al. Laser-capture microdissection Nat Protoc 2006;1:586-603.

28. Perkins DN, Pappin DJ, Creasy DM, et al. Probability-based protein identification by searching sequence databases using mass spectrometry data. Electrophoresis 1999;20:3551-3567.

29. Khoor A, Myers JL, Tazelaar HD, et al. Amyloid-like pulmonary nodules, including localized light-chain deposition: clinicopathologic analysis of three cases. Am J Clin Pathol 2004;121:200-204.

30. Rostagno A, Frizzera G, Ylagan L, et al. Tumoral non-amyloidotic monoclonal immunoglobulin light chain deposits ('aggregoma'): presenting feature of B-cell dyscrasia in three cases with immunohistochemical and biochemical analyses. Br J Haematol 2002;119:62-69.

31. Lin J, Markowitz GS, Valeri AM, et al. Renal monoclonal immunoglobulin deposition disease: the disease spectrum. J Am Soc Nephrol 2001;12:1482-1492.

32. Fischer L, Korfel A, Stoltenburg-Didinger G, et al. A 19-year-old male with generalized seizures, unconsciousness and a deviation of gaze. Brain Pathol 2006;16:185-186, 187.

33. Popovic M, Tavcar R, Glavac D, et al. Light chain deposition disease restricted to the brain: the first case report. Hum Pathol 2007;38: 179-184.

34. Ge F, Yao J, Fu X, et al. Amyloidosis in transgenic mice expressing murine amyloidogenic apolipoprotein A-II (Apoa2c). Lab Invest 2007;87:633-643. 